BIODIK: Jurnal IImiah Pendidikan Biologi
ISSN 2580-0922 (online), ISSN 2460-2612 (print)
Volume 7, Nomor 01, Tahun 2021, Hal. 1-12
Available online at:
https://online-journal.unja.ac.id/biodik

Research Article

open access

\title{
Kajian Etnobotani Tumbuhan Bungur (Lagerstroemia Speciosa) di Kawasan Hutan Bukit Tamiang Kabupaten Tanah Laut sebagai Buku IImiah Populer
}

\section{(Ethnobotany Study of Bungur (Lagerstroemia speciosa) in Tamiang Hill Forest of Tanah Laut Regency as a Popular Scientific Book)}

\author{
Siti Muthia Rahmah*, Dharmono, Aminuddin Prahatama Putra \\ Program Studi Pendidikan Biologi FKIP Universitas Lambung Mangkurat \\ Jl. Brigjen H. Hasan Basri, Pangeran, Kota Banjarmasin, Kalimantan Selatan 70123-Indonesia \\ Corresponding Author Email: muthiarahmah25@gmail.com
}

\begin{tabular}{|c|c|}
\hline Informasi Artikel & ABSTRACT \\
\hline $\begin{array}{l}\text { Submit: } 04-12-2020 \\
\text { Diterima: } 22-02-2021 \\
\text { Dipublikasikan: } 12-03-2021\end{array}$ & $\begin{array}{l}\text { The development of the popular scientific book Ethnobotany of the Bungur plant } \\
\text { (Lagerstroemia speciosa) is important because it can raise the local potential of the } \\
\text { community in the Bukit Tamiang area and as an enrichment material for the } \\
\text { Ethnobotany course in the ULM Biology education program. This study aims to } \\
\text { describe the ethnobotany study of Bungur (Lagerstroemia speciosa) in the Bukit } \\
\text { Tamiang forest area, Tanah Laut Regency, South Kalimantan and to describe the } \\
\text { validity and practicality of the contents of popular scientific books. This method uses } \\
\text { two types of research, namely descriptive research, interviews with the public about } \\
\text { the Bungur plant and followed by the formative evaluation of the Tessmer test for } \\
\text { validation and practicality of the contents of Popular Scientific Books. The results of } \\
\text { research on Bungur plants (Lagerstroemia speciosa) in the Bukit Tamiang forest area } \\
\text { have various studies including botanical, ethno-ecological, ethno-pharmacological, } \\
\text { ethnoanthropological, ethno-economic, and ethno-linguistic studies. The conclusion } \\
\text { from the development of a popular scientific book on the study of the ethnobotany of } \\
\text { the Bungur plant (Lagerstroemia speciosa) is that expert test results were obtained } \\
\text { by two validators with an average value of 90.3\% with very valid criteria and the } \\
\text { results of the practicality of the content on individual tests by three students getting } \\
\text { average results. percentage 3,7\% with very good criteria. The advantages of } \\
\text { developing a popular scientific book on the ethnobotany study of the Bungur plant } \\
\text { (Lagerstroemia speciosa) can be used by students as an enrichment material for } \\
\text { Ethnobotany courses and can be read by the wider community because this popular } \\
\text { scientific book developed is structured in such a way that it is easily understood by } \\
\text { readers. However, the weakness is that the learning material contained in this } \\
\text { developed book is insufficient so that further research is needed. } \\
\text { Key words: Ethnobotany, Bungur (Lagerstroemia speciosa), Popular Scientific Book }\end{array}$ \\
\hline Penerbit & ABSTRAK \\
\hline $\begin{array}{l}\text { Program Studi Pendidikan } \\
\text { Biologi, Fakultas Keguruan dan } \\
\text { Ilmu Pendidikan, Universitas } \\
\text { Jambi }\end{array}$ & $\begin{array}{l}\text { Pengembangan buku ilmiah populer Etnobotani tumbuhan Bungur (Lagerstroemia } \\
\text { speciosa) penting dilakukan karena dapat mengangkat potensi lokal masyarakat di } \\
\text { kawasan Bukit Tamiang dan sebagai bahan pengayaan untuk mata kuliah Etnobotani } \\
\text { di prodi pendidikan Biologi ULM. Penelitian ini bertujuan untuk mendeskripsikan } \\
\text { kajian etnobotani tumbuhan Bungur (Lagerstroemia speciosa) di kawasan hutan } \\
\text { Bukit Tamiang Kabupaten Tanah Laut Kalimantan Selatan dan mendeskripsikan } \\
\text { validitas serta kepraktisan isi buku ilmiah popular. Metode ini menggunakan dua jenis } \\
\text { penelitian, yaitu penelitian deskriptif wawancara kepada masyarakat tentang } \\
\text { tumbuhan Bungur dan dilanjutkan evaluasi formatif uji Tessmer untuk validasi dan } \\
\text { kepraktisan isi Buku Ilmiah Populer. Hasil penelitian tumbuhan Bungur } \\
\text { (Lagerstroemia speciosa) di kawasan hutan Bukit Tamiang memiliki berbagai kajian } \\
\text { diantaranya kajian botani, etno-ekologi, etno-farmakologi, etnoantropologi, etno- } \\
\text { ekonomi, dan etno-linguistik. Kesimpulan dari pengembangan buku ilmiah populer }\end{array}$ \\
\hline
\end{tabular}


kajian etnobotani tumbuhan Bungur (Lagerstroemia speciosa) yaitu didapatkan hasil uji pakar oleh dua validator dengan nilai rata-rata 90,3\% dengan kriteria sangat valid dan hasil kepraktisan isi pada uji perorangan oleh tiga mahasiswa mendapatkan hasil rata-rata persentase $3,7 \%$ dengan kriteria sangat baik. Kelebihan dari pengembangan buku ilmiah populer kajian etnobotani tumbuhan Bungur (Lagerstroemia speciosa) ini dapat digunakan oleh mahasiswa sebagai bahan pengayaan mata kuliah Etnobotani dan dapat dibaca oleh masyarakat luas karena buku ilmiah populer yang dikembangkan ini disusun sedemikian rupa sehingga mudah dipahami oleh pembaca. Namun, kelemahannya yaitu kurang luasnya materi pembelajaran yang dimuat pada buku yang dikembangkan ini sehingga perlu adanya penelitian lanjutan.

Katakunci: Etnobotani, Lagerstroemia speciosa, Buku Ilmiah Populer

This BIODIK : Jurnal IImiah Pendidikan Biologi is licensed under a CC BY-NC-SA (Creative Commons Attribution-ShareAlike 4.0 International License)

\section{PENDAHULUAN}

Etnobotani merupakan suatu kajian yang mempelajari hubungan budaya manusia dengan alam tumbuhan di sekitarnya secara langsung tanpa merusak atau mengeksploitasinya. Kehidupan sumber daya manusia sebagian besar didukung dengan memanfaatkan tumbuhan untuk kepentingan pengobatan, bahan kecantikan, upcara adat, dan budaya (Suryadarma, 2008). Kajian etnobotani dibagi menjadi 6 kajian yaitu kajian botani, kajian etno-farmakologi, kajian etno-ekologi, kajian etnoantropologi, kajian etno-ekonomi, dan kajia etno-linguistik (Martin, 1998). Pemahaman tentang etnobotani penting untuk menilai hubungan ekologis antara manusia dan ekosistem yang termanipulasi, oleh karena itu adapun peran etnobotani antara lain yaitu konservasi tumbuhan, ketahanan pangan, memperkuat identitas etnik dan nasionalisme, memperbesar keamanan fungsi lahan produktif, dan penemuan obat-obatan baru (Hakim, 2014).

Bahan ajar merupakan salah satu sumber media belajar yang dapat berupa buku, LKS, handout, dan media lainnya yang dapat digunakan oleh pendidik sehingga tujuan pembelajaran dapat tercapai (Pratiwi, et. al., 2014). Salah satu media pembejalaran yang dapat membantu proses pembelajaran yaitu buku ilmiah populer karena terdapat materi yang lengkap dan bahasa yang sederhana sehingga dapat memudahkan pembaca dalam memahami materi yang terdapat dalam buku Latifah, et. al. (2018). Tujuan penelitian pengembangan seperti itu adalah mengidentifikasi pemanfaatan pengolahan dan pelestarian tumbuhan yang dilakukan oleh masyarakat lokal (Wibowo, 2012). Menurut Mahrudin (2018) bahan ajar berbasis lokal adalah media penyampaiannya dikaitkan dengan lingkungan alam, lingkungan sosial dan lingkungan budaya serta kebutuhan pembangunan daerah setempat yang perlu diajarkan kepada siswa. Pembelajaran berbasis lokal sangat bermanfaat bagi pemaknaan proses dan hasil belajar karena siswa mendapatkan pengalaman belajar yang kontekstual dan bahan apersepsi untuk memahami konsep ilmu pengetahuan dalam budaya lokal yang dimiliki. Beberapa penelitian bahan ajar bermuatan lokal yang telah dilakukan diantaranya adalah Hardiansyah, et al.. (2018) tentang "Keragaman Jenis Vegetasi di Kawasan Rawa Tanpa Pohon Desa Bati-Bati Kabupaten Tanah Laut sebagai Materi Pengayaan Mata Kuliah Ekologi Lahan Basah" dan Mahrudin, et al. (2018) yang mengembangkan Handout tentang struktur populasi tumbuhan tepi sungai sebagai materi penunjang mata kuliah ekologi tumbuhan dapat meningkatkan kemampuan berfkir kritis mahasiswa. Berdasarkan hasil-hasil penelitian tersebut, nampak bahwa peluang untuk mengembangkan bahan ajar masih cukup luas. 
Penelitian ini berupa bahan ajar buku ilmiah populer dibandingkan dengan bahan ajar lainnya buku ilmiah populer memiliki beberapa keunggulan salah satunya yaitu menggunakan bahasa yang sederhana dan gambar-gambar yang dimuat dalam buku tersebut hampir sama seperti aslinya dan memiliki standar keilmiahan dalam penulisannya. Buku ilmiah populer lebih banyak diciptakan dengan jalan menyadur, megutip, dan meramu informasi dari berbagai tulisan orang lain daripada menulis murni gagasan, pendapat, dan pernyataan (Yunizarrakha, et al., 2018). Banyak bentuk ilmu pengetahuan populer yang telah muncul misalnya berupa buku, surat kabar, artikel majalah, blog web, dan siaran pers yang semakin sering digunakan untuk mengkomunikasikan ilmu pengetahuan kepada masyarakat awam. Peneliti memilih Buku IImiah Populer dalam hasil penelitiannya karena buku lebih dikenal sebagai sumber pengetahuan dari zaman dulu sampai sekarang sehingga buku yang dikembangkan menjadi ilmiah populer ini bukan hanya untuk pengetahuan pendidikan disekolah ataupun kuliah tetapi juga bisa untuk masyarakat awam termasuk daerah tempat penelitian ini yang masyarakatnya masih mengikuti pengetahuan turun temurun dari dulu dalam usaha dibandingkan mengembangkan yang lebih modern seperti jaringan internet secara online. Harapan dengan adanya buku ilmiah populer ini pendidik, peserta didik dan kalangan masyarakat awam akan lebih mudah mendapatkan pengetahuan dari alam sekitarnya untuk kehidupan sehari-hari ataupun perekonomiannya.

Lokasi penelitian yaitu di kawasan hutan Bukit Tamiang Kabupaten Tanah Laut Kalimantan Selatan. Hutan ini terdapat di puncak Bukit Tamiang yang dikelilingi padang rumput dan masih banyak tumbuhan lain seperti pohon dan semak. Perjalanan menuju Bukit Tamiang tersebut terdapat kebun masyakarakat dan ada juga tumbuhan liar dengan sendirinya. Perjalanan menuju bukit juga terdapat beberapa pagar yang berfungsi sebagai pembatas antar wilayah kepemilikan masyarakat untuk kebun dan wilayah wisata karena pada tahun 2019 Bukit Tamiang Kabupaten Tanah laut resm dijadikan sebagai objek wisata.

Beranekaragam tumbuhan di hutan Bukit Tamiang salah satunya adalah tumbuhan Bungur (Lagerstroemia speciosa) yang memiliki bunga yang lebat berwarna keunguan sehingga menarik perhatian disaat pertama melihat, selain itu ciri pohon berukuran tinggi, batang berbentuk bulat berwarna coklat, daunnya tunggal bertangki pendek, dan yang lebih unik bisa terlihat dibagian buah tumbuhan Bungur (Lagerstroemia speciosa) yang mana saat muda berwarna hijau dengan tekstur sangat keras namun saat tua buah berwarna coklat dengan tekstur yang hanya tersisa lapisan luar buah kering saja. Menurut Heyne (1987) nama Bungur (Lagerstroemia speciosa) dikenal di berbagai daerah diantaranya masyarakat Melayu, Sunda, dan Kalimantan deangan sebutan Bungur karena penyebaran pohon Bungur ini dapat ditemukan dihutan pada tanah gersang maupun ditanah subur. Bungur (Lagerstroemia speciosa) memiliki manfaat hampir disemua bagian pohon, pada kajian farmakologi digunakan untuk mengobati stroke, sakit gigi, bisul dan batuk. Kajian ekologi digunakan sebagai penghijauan hutan dan hiasan jalan. Kajian antropologi sebagai penanda musim hujan dan penjaga buah tumbuhan lain. Kajian ekonomi sebagai kayu bakar, pondok dan pagar ternak. Manfaatmanfaat antar kajian tersebut tidak banyak diketahui oleh orang namun tumbuhan ini banyak tersebar diberbagai tempat selain Kalimantan, sehingga perlu dilakukan penelitian tentang etnobotani tumbuhan Bungur (Lagerstroemia speciosa). Hasil penelitian etnobotani tumbuhan ini kemudian dikembangkan menjadi bahan ajar berbentuk Buku IImiah Populer.

\section{METODE PENELITIAN}

Penelitian ini menggunakan pendekatan diskriptif pada penelitian kajian etnobotani terhadap tumbuhan Bungur (Lagerstroemia speciosa) dan dilanjutkan dengan menggunakan model 
pengembangan bahan ajarnya yang menggunakan model Education Design Research (EDR). Education Design Research (EDR) akan menghasilkan rancangan-rancangan program, strategi pembelajaran, bahan ajar, produk dan system yang dapat digunakan untuk memecahkan masalah dalam pembelajaran atau pendidikan secara empiris (Lidinillah, 2012). Melalui evaluasi Formatif Tessmer dengan tahap-tahap pengembangan yang dibatasi hanya meliputi: 1) evaluasi diri (self evaluation); 2) uji pakar (expert review); dan 3) uji perorangan (one to one). Penelitian ini dilakukan di kawasanhutan Bukit Tamiang Kabupaten Tanah Laut dan dikawasan kampus FKIP ULM selama 1 semester. Tumbuhan Bungur (Lagerstroemia speciosa) merupakan sampel penelitian yang dilakukan secara sampel total pada hutan Bukit Tamiang seluas 1,05 hektar. Alat yang digunakan berupa alat parameter lingkungan seperti hygrometer, soiltester, dan thermometer sedangkan bahannya adalah tumbuhan Bungur (Lagerstroemia speciosa). Data buku ilmiah dianalisis dengan cara menghitung skor validitas dari hasil validasi ahli :

$\mathrm{V}=\frac{T S e}{T S h} \times 100 \%$

Keterangan:

$\checkmark \quad$ : Validitas

TSe : total skor validasi dari validator

TSh : : total skor maksimal yang diharapkan (Akbar, 2013)

Produk yang dihasilkan berupa buku ilmiah populer etnobotani tumbuhan bungur (Lagerstroemia speciosa) melalui tahapan pengembangan menggunakan desain Tessmer (1998) yang terdiri atas dua langkah yakni uji pakar dan uji perorangan. Hasil uji pakar didapatkan dari hasil uji validasi ahli oleh tiga validator dan uji perorangan didapatkan dari hasil uji keterbacaan yang melibatkan tiga mahasiswa dengan kriteria mahasiswa yang telah lulus mata kuliah Etnobotani pada program studi pendidikan Biologi ULM.

\section{HASIL PENELITIAN DAN PEMBAHASAN}

\section{Kajian Etnobotani}

Hasil kajian botani pada tumbuhan Bungur (Lagerstroemia speciosa) yang meliputi kajian botani, etno-farmakologi, etno-linguistik, etno-ekonomi, etno-antropologi,dan etno-ekologi didapatkan hasil sebagaimana pada Table 1.

Tabel 1. Etnobotani Bungur (Lagerstroemia speciosa)

\begin{tabular}{|c|c|c|}
\hline No & Kajian & Manfaat \\
\hline 1 & Botani & $\begin{array}{l}\text { Pohon sedang, akar tunggang bulat serabut banyak, batang simpodial arah } \\
\text { tumbuh keatas ber warna coklat, daun memanjang tata letak berseling dan } \\
\text { bunga majemuk berbatas, serta buah sejati tunggal kering tipe berbelah } \\
\text { banyak. }\end{array}$ \\
\hline 2 & Etno-Linguistik & Pemberian nama Bungur karena bunga nya yang mudah rontok (lungur). \\
\hline 3 & Etno-Ekonomi & Kayu bakar, pagar ternak dan pondok \\
\hline 4 & Etno-Farmakologi & $\begin{array}{l}\text { Obat stroke bahan daun, obat sakit gigi bahan akar muda, obat bisul bahan } \\
\text { buah, dan obat batuk bahan air yang mengalir pada batang }\end{array}$ \\
\hline 5 & Etno-Antropologi & $\begin{array}{l}\text { Dipercaya sebagai penanda musim hujan dan penjaga buah tumbuhan lain } \\
\text { yang dimatangkan. }\end{array}$ \\
\hline 6 & Etno-Ekologi & $\begin{array}{l}\text { Struktur populasi berbentuk dasar pyramid luas dengan persebaran pra- } \\
\text { reprodukti dan reproduktif lebih banyak dibandingkan post-reproduktif, } \\
\text { tumbuhan ini di gunakan sebagai penghijauan, peneduh dan hiasan jalan. }\end{array}$ \\
\hline
\end{tabular}


Penelitian kajian etnobotani tumbuhan Bungur (Lagerstroemia speciosa) memiliki kelebihan informasi pengetahuan yang lebih banyak tentang tumbuhan ini bahwa begitu banyak manfaat yang bisa dihasilkan dalam satu tumbuhan Bungur (Lagerstroemia speciosa) ini saja, tetapi juga memiliki kekurangan dalam penelitian ini seperti kajian farmakologi yang belum di uji langsung secara laboratorium dan penelitian pengetahuan tumbuhan Bungur (Lagerstroemia speciosa) ini terbatas dari ruang lingkup kawasan hutan Bukit Tamiang Kabupaten Tanah Laut Kalimantan Selatan.

\section{a. Kajian botani}

Tumbuhan Bungur (Lagerstroemia speciosa) merupakan pohon sedang dengan akar tunggang bulat serabut banyak, batang simpodial arah tumbuh keata berwarna coklat, daun memanjang tata letak berseling, bunga majemuk berbatas, dan buah sejati tunggal kering tipe berbelah banyak. Kedudukan tumbuhan Bungur (Lagerstroemia speciosa) dalam taksonomi menurut Cronquist (1981) sebagai berikut:

$\begin{array}{ll}\text { Kingdom } & : \text { Plantae } \\ \text { Divisi } & \text { : Magnoliophyta } \\ \text { Kelas } & : \text { Magnoliopsida } \\ \text { Ordo } & : \text { Myrtales } \\ \text { Famili } & : \text { Lythraceae } \\ \text { Genus } & : \text { Lagerstroemia } \\ \text { Spesies } & : \text { Lagerstroemia } \\ & \text { speciosa }\end{array}$

Morfologi hasil pengamatan tidak berbeda dengan yang dinyatakan oleh Liu (2001) bahwa pohon Bungur (Lagerstroemia speciosa) tingginya berkisaran 10- $30 \mathrm{~m}$ dengan batang berbentuk bulat berwarna coklat muda, sedangkan menurut Suradji (2017) pohon Bungur (Lagerstroemia speciosa) berukuran besar dan diameter batangnya bias mencapai $150 \mathrm{~cm}$, tetapi pada umumnya tinggi pohon 25-30 m dan diameter batangnya $60-80 \mathrm{~cm}$. Batang bulat berwarna coklat muda biasanya agak bengkok tetapi pada tempat-tempat tumbuh yang baik batang tumbuh lurus beralur agak dalam dan percabangannya dimulai dari bagian pangkal. Menurut Liu (2001) daun Bungur (Lagerstroemia speciosa) berdaun tungggal dan bertangkai pendek, helaian daun berbentuk oval atau memanjang dan tekstur daun seperti kertas, panjang daun berkisaran 9-28 cm dan lebar mencapai 4- $12 \mathrm{~cm}$ berwarna hijau tua. Morfologi bunga hampir sama yang dijelaskan Heyne (1987) Bungur (Lagerstroemia speciosa) majemuk berwarna ungu dan tersusun dalam malai yang panjangnya $10-15 \mathrm{~cm}$, bunga terletak dari ketiak daun atau ujung ranting. Menurut Suradji (2017) Bungur berbunga 2 kali dalam setahun yaitu akhir November- Desember dan buln Mei- Juni tetapi bias dijumpai diluar bulan tersebut karena mengkondisikan pada saat musim penghujan. Menurut Heyny (1987) buah Bungur (Lagerstroemia speciosa) berbentu bulat dengan panjang 1,8- 2,5 cm diameternya 1,5- $2 \mathrm{~cm}$, ujung buah runcing seperti jarum dengan panjang $0,3 \mathrm{~mm}$. buah saat muda berwarna hijau namun apabila sudah tua berwarna coklat, buah ini masak memerlukan waktu 3- 4 bulan.

\section{b. Kajian Etno-Linguistik}

Kajian Etno-Linguistik menurut Martin (1995) adalah kajian yang mempelajari tentang asal mula kejadian pemberian nama suatu tumbuhan dalam bahasa daerah tersebut. Berdasarkan wawancara dengan masyarakat Desa Kandanagan Baru Suku Banjar tumbuhan Bungur (Lagerstroemia 
speciosa) dikenal masyarakat dengan sebutan Bungur. Kata Bungur menurut masyarakat disampaikan orang terdahulu yang dianggap dari bunganya yang cepat rontok (lungur). Responden yang diwawancari asli banjar dan mengatakan bungur berasal dari bahasa Banjar. Pengetahuan nama tumbuhan Bungur (Lagerstroemia speciosa) disampaikan ke anak responden hanya jika anak menanyakan. Menurut Suradji (2017) nama lokal atau daerah tumbuhan Bungur (Lagerstroemia speciosa) di Indonesia antar daerah seperti Sumatera dan Kalimantan (Bungur); Lampung (Bungur kuwal, Bungur bener); Palembang (Bungur tekuyung); Sunda (Bungur); Jawa tengah (Ketangi, Laban, Wungu); Madura (Bhungor, Wungur).

\section{c. Kajian Etno-Ekonomi}

Kajian Etno-Ekonomi ini menurut Dharmono (2019) melihat pada situasi masyarakat dalam suatu kawasan tertentu. Hal tersebut dapat dilihat dari aktivitas produktif setiap keluarga dalam masyarakat tersebut. Kajian Etno-Ekonomi biasanya membahas megenai fungsi tumbuhan untuk pembinaan rumah, bahan bakar, makanan ternak, dan juga sayuran untuk konsumsi masyarakat. Penekanan tentang pemanfaatan tumbuhan saat ini mengarah pada konsep kelestarian terutama yang berhubungan dengan laju pemanfaatan tumbuhan dengan laju pertambahan penduduk tersebut. Tumbuhan Bungur (Lagerstroemia speciosa) digunakan masyarakat sebagai kayu bakar, pondok, dan pagar ternak. Bagian yang digunakan adalah batang karena batang tumbuhan Bungur (Lagerstroemia speciosa) berukuran besar, kuat dan panjang sehingga cocok untuk diolah sesuai keperluan. Menurut Bramasto (2015) tanaman Bungur (Lagerstroemia speciosa) terutama banyak dimanfaatkan sebagai tanaman hias di kota, karena tanaman ini mempunyai bunga yang menarik, tajuk yang rimbun dan mudah untuk ditanam, selain itu bagian-bagian tanaman anatara lain daun dapat digunakan untuk penyakit kulit, bubur daunnya untuk obat malaria, rebusan daun tua dan buah masak untuk obat diabetes, sedangkan kulit batang untuk obat diare.

\section{d. Kajian Etno-Farmakologi}

Kajian Etno-Farmakologi menurut Martin (1995) adalah kajian tentang penggunaan tumbuhan yang berfungsi sebagai obat atau ramuan yang dihasilkan penduduk setempat untuk pengobatan. Tumbuhan Bungur (Lagerstroemia speciosa) memiliki manfaat untuk obat hampir semua bagian dari tumbuhan dapat digunakan menurut masyarakat Kandangan Baru yaitu bagian daun, batang, buah dan akar. Daun tumbuhan Bungur (Lagerstroemia speciosa) dapat mengobati penyakit stroke dengan bahan daun kering 7 helai direbus air sampai mendidih lalu diminum, begitu juga dengan obat sakit gigi dengan bahan akar muda direbus air lalu diminum. Buah muda tumbuhan ini dapat mengobati bisul dengan cara di panaskan sampai menghitam lalu tempelkan pada kulit yang berbisul dan batang tumbuhan apabila dipatahkan terdapat air yang mengalir bias langsung diminum untuk obat batuk.

Salah satu tumbuhan yang dapat menjadi bahan bagi ramuan-ramuan tradisional itu adalah daun dari pohon Bungur (Lagerstroemia speciosa) telah banyak digunakan sebagai metode pengobatan tradisional untuk mengatasi diabetes mellitus di wilayah Asia Tenggara selama bertahuntahun. Ekstrak daun Bungur (Lagerstroemia speciosa) telah diketahui bersifat antiobesitas (Suzuki et al., 1999). Biji dan daun tumbuhan ini bias digunakan sebagai obat diabetes dan darah tinggi, sedangkan bagian kulit batang digunakan untuk mengobati diare, disentri dan kencing darah. Daun bungur memiliki kandungan kimia seperti saponin, flavonoid, dan tannin, sedangkan pada kulit batang mengandung flavonoid dan tannin, dan biji bungur mengandung senyawa plantisul yaitu sejenis zat insulin nabati serta mempunyai aktivitas seperti insulin (Dalimartha, 2003) 


\section{e. Kajian Etno-Antropologi}

Tumbuhan Bungur (Lagerstroemia speciosa) tidak digunakan atau dimanfaatkan dalam upacara adat atau kegiatan adat tetapi masyarakat setempat memiliki kepercayaan bahwa tumbuhan Bungur (Lagerstroemia speciosa) tersebut bagian bunganya dipercayai apabila tumbuhannya berbunga ini pertanda musim hujan. Dwiyani (2013) mengatakan pada musim kemarau tanaman Bungur (Lagerstroemia speciosa) menggugurkan daunnya, bunga- bunga muncul bersamaan dengan munculnya daun-daun baru, hal itulah yang membuat masyarakat desa Kandangan Baru percaya bahwa tumbuhan ini berbunga menandakan musim hujan. Bagian buah Bungur (Lagerstroemia speciosa) juga dipercaya masyarakat desa Kandangan Baru sebagai penjaga buah tumbuhan lain yang ingin dimatangkan agar tidak dimangsa burung atau hewan lain dikarenakan buah bungur yang keras dan banyak sehingga bias menutupi buah lain. Berdasarkan hasil wawancara tersebut menunjukkan bahwa hampir semua masyarakat mengetahui kepercayaan tersebut tentang tumbuhan Bungur (Lagerstroemia speciosa) karena pengetahuan tersebut diperoleh dari orang-orang terdahulu dan dilakukan secara turun-temurun. Penegtahuan yang diperoleh tersebut tidak semua diajarkan kepada anak mereka tetapi ada yang disampaikan secara langsung oleh orang tua atau dari orang disekitarnya, tergantung pada anaknya lagi mau mendengarkan atau tidak saat disampaikan.

\section{f. Kajian ekologi}

Dari data lapangan, didapatkan hasil pengukuran parameter lingkungan tumbuhan Bungur (Lagerstroemia speciosa), dapat dilihat pada Tabel 2.

Tabel 2. Parameter lingkungan tumbuhan Bungur (Lagerstroemia speciosa)

\begin{tabular}{llc}
\hline No & Parameter yang diukur & Kisaran \\
\hline 1. & Kelembaban udara $(\%)$ & $60-98$ \\
2. & Suhu udara (OC) & $22-32$ \\
3. & Kecepatan angin (m/s) & $0,1-3,8$ \\
4. & pH tanah & $5,8-6,5$ \\
5. & Kelembaban tanah (\%) & $88-98$ \\
6. & Intensitas cahaya (Lux) & $219->20000$ \\
\hline
\end{tabular}

Penelitian yang dilakukan di hutan Bukit Tamiang diketahui bahwa tumbuhan Bungur (Lagerstroemia speciosa) banyak ditemukan. Menurut Liu (2011) di Jawa tumbuhan Bungur (Lagerstroemia speciosa) dapat tumbuh sampai ketinggian $800 \mathrm{mdpl}$ dengan pohon setinggi $10-30 \mathrm{~m}$. Berdasarkan hasil perhitungan tumbuhan Bungur (Lagerstroemia speciosa) yang terdapat dikawasan hutan Bukit Tamiang hasil penjumlahan dari kategori individu dewasa termasuk dalam kategori Least Concern tidak kritis pada status IUCN (2014) karena jumlahnya $>25$ individu dewasa km² yaitu sebesar 14.000 individu/ $/ \mathrm{km}^{2}$, dapat disimpulkan bahwa populasi tumbuhan Bungur (Lagerstroemia speciosa) dikawasan Hutan Bukit Tamiang banyak ditemukan fase pra reproduksi daripada fase reproduksi dan fase post reproduksi yang menunjukkan perkembangan jumlah kelompok umur muda lebih banyak dibandingkan dengan kelompok umur tua. Tumbuhan Bungur (Lagerstroemia speciosa) di hutan Bukit Tamiang digunakan sebagai peneduh dengan upaya pelestariannya memberikan tumbuhan hidup liar dihabitatnya dengan hanya mengambil bagian yang diperlukan dan tidak menebang habis. Pemanfaatan tumbuhan Bungur (Lagerstroemia speciosa) juga ditanam sebagai penghias jalan. 


\section{Validitas buku ilmiah popular}

Buku ilmiah popular adalah buku yang berpegang kepada standar ilmiah, tetapi ditampilkan dengan bahasa umumnya yang mudah dipahami oleh masyarakat umum dan tampilan yang menarik perhatian pembaca (Wiana, 2011). Validasi terhadap produk buku ilmiah popular ini dilakukan oleh 2 pakar ahli sebagai validator, setelah melalui tahap revisi didapatkan hasil yang terlihat pada Tabel 3.

Tabel 3. Hasil Uji Validasi Buku IImiah Populer

\begin{tabular}{|c|c|c|}
\hline Indikator Penilaian & Aspek & Rata-Rata \\
\hline \multirow[t]{4}{*}{ Aspek Kohersi } & Setiap paragraf dalam BIP memiliki satu ide pokok & 3,5 \\
\hline & Menghubungkan antar kalimat menggunakan kata penghubung & 3,5 \\
\hline & Ide-ide disampaikan secara berurutan & 3 \\
\hline & $\begin{array}{l}\text { Kalimat telah mengarahkan kepada pembaca kepada pemahaman } \\
\text { isi buku }\end{array}$ & 4 \\
\hline \multirow[t]{2}{*}{ Keterbacaan } & Isi teks sesuai dengan itngkat usia/tingkat pendidikan. & 3 \\
\hline & Kaliamat dan banyak kata dapat mengukur tingkat pembaca & 3 \\
\hline \multirow{2}{*}{$\begin{array}{l}\text { Kosa kata: } \\
\text { Ungkapan, kerja, } \\
\text { pilihan yang } \\
\text { berlebihan }\end{array}$} & Pemakaian ungkapan digunakan secara terbatas & 4 \\
\hline & $\begin{array}{l}\text { Kata atau ungkapan yang digunakan tidak menggunakan banyak } \\
\text { kosa kata }\end{array}$ & 4 \\
\hline $\begin{array}{l}\text { Kalimat aktif dan } \\
\text { pasif }\end{array}$ & Menggunakan kalimat aktif dan pasif & 4 \\
\hline Format & $\begin{array}{l}\text { Berbentuk tulisan ilmiah yang menampilkan bukti berupa data atau } \\
\text { gambar yang disusun secara sistematis }\end{array}$ & 3,5 \\
\hline Metode penulisan & Kesederhanaan dan kemenarikan sebuah tulisan & 3,5 \\
\hline $\begin{array}{l}\text { Aplikasi dan } \\
\text { implikasi }\end{array}$ & $\begin{array}{l}\text { Menggunakan masalah yang ada di dunia nyata untuk menarik } \\
\text { pembaca }\end{array}$ & 4 \\
\hline $\begin{array}{l}\text { Definisi dan } \\
\text { Implikasi }\end{array}$ & $\begin{array}{l}\text { Menggunakan masalah yang ada di dunia nyata untuk menarik } \\
\text { pembaca }\end{array}$ & 3,5 \\
\hline \multirow{4}{*}{$\begin{array}{l}\text { Gaya lain Perangkat } \\
\text { : narasi, humor, dan } \\
\text { analogi }\end{array}$} & Menggunakan analogi untuk menjelaskan ide yang kompleks. & 3,5 \\
\hline & Menggunakan narasi untuk menjelaskan ide yang disajikan & 3,5 \\
\hline & Total Skor Rata-rata Validasi & $90,3 \%$ \\
\hline & Kriteria Validasi & Sangat valid \\
\hline
\end{tabular}

Hasil validasi menunjukkan nilai $90,3 \%$ dengan kriteria sangat valid, artinya produk buku ilmiah popular yang dibuat sudah valid dan bias dilnjutkan ketahap selanjutnya yaitu tahap uji kepraktisan isi. Uji validasi yang dilakukan bertujuan untuk mengetahui kelemahan atau kekurangan dari produk yang telah dikembangka berdasarlan masukan-masukan yang diberikan oleh validator. Menurut Hera (2014) hasil validasi buku ilmiah populer dengan kriteria valid menunjukkan bahwa bahan ajar yang dikembangkan mempunyai kualitas yang baik dan dapat dipergunakan. Uji validasi masih mempunyai saran-saran dari 2 validator yang tetap harus diperbaiki. Menurut Aminuddin (2016) masalah- masalah ini diselesaikan dalam pembelajaran untuk dipecahkan, sehingga kepedulian mahasiswa terhadap masalah social akan bangkit dan mereka mencoba mencari solusi untuk masalah tersebut.

\section{Kepraktisan isi buku ilmiah populer}

Uji perorangan atau uji kepraktisan isi yang dilakukan oleh 3 mahasiswa Pendidikan Biologi FKIP ULM Banjarmasin yang telah mengambil dan dinyatakan lulus pada mata kuliah Etnobotani. Hal tersebut dikarenakan untuk menilai bahwa bahan ajar yang dikembangkan sesuai dengan kondisi mahasiswa yang mereka gunakan sebagai bahan ajar dalam pembejaran. Uji coba kepraktisan isi ini dilakukan untuk mengetahui keterlaksanaan, manfaat, dan efektivitas penggunaan media dalam pembelajaran untuk bahan revisi atau penyempurnaan sebuah produk (Putri, et al., 2020). Sementara 
kepraktisan isi dari respon mahasiswa terhadap pembelajaran selam uji perorangan dianalisis secara deskriptif berdasarkan rata- rata skor dengan kriteria penilaian berdasar pada Fitriansyah, et al. (2018). Hasil uji kepraktisan isi buku ilmiah populer dilihat pada Tabel 4.

Tabel 4. Hasil Kepraktisan Isi Mahasiswa

\begin{tabular}{clccc}
\hline N0 & \multicolumn{1}{c}{ Pernyataan } & M1 & M2 & M3 \\
\hline 1 & Setiap bagian yang dipelajari mudah dipahami & 4 & 4 & 4 \\
2 & $\begin{array}{l}\text { Keseluruhan isi BIP lengkap ( Cover, Editorial, Kata Pengantar, } \\
\text { Daftar Isi, Pendahuluan, Isi Pokok, Referensi, Indeks, Glosarium) }\end{array}$ & 4 & 4 & 4 \\
3 & Kata-kata yang digunakan mudah dipahami & 4 & 3 & 3 \\
\hline $\mathbf{4}$ & Kualitas gambar bagus dan dapat dipahami maksudnya & 4 & 4 & 4 \\
$\mathbf{5}$ & Kesalahan ketik atau tata bahasa tidak ditemukan. & 3 & 4 & 3 \\
$\mathbf{6}$ & Foto pada cover jelas dan dapat dipahami maksudnya & 4 & 3 & 4 \\
\hline & Jumlah & $\mathbf{2 3}$ & $\mathbf{2 2}$ & $\mathbf{2 2}$ \\
\hline & Skor Kepraktisan BIP & $\mathbf{3 , 8}$ & $\mathbf{3 , 7}$ & $\mathbf{3 , 7}$ \\
\hline & Rata-rata & & $\mathbf{3 , 7}$ & \\
\hline & Kriteria validasi & & Sangat baik
\end{tabular}

Hasil uji kepraktisan isi menunjukkan buku ilmiah populer mmeiliki kriteria sangat baik yaitu 3,7. Hal tersebut menunjukkan bahwa buku ilmiah populer mudah untuk dipahami dan mudah diaplikasikan materinya dalam kehidupan sehari- hari oleh mahasiswa sebagai media bahan ajar untuk pembelajaran. Menurut Murdiah (2018) aktivitas mahasiswa yang sudah tergolong baik. Hal itu menunjukkan bahwa mahasiswa telah tertarik dengan pembelajaran yang akan mereka terima sehingga memicu semangat belajar dan berdampak pada aktivitas siswa. Uji kepraktisan isi ini semua aspek yaitu aspek kelengkapan, aspek keterbacaan, dan aspek penyajian memiliki rentang penilaian 3- 4, penilaian ini diberikan oleh 3 mahasiswa yang terpilih. Menurut Suryani (2017) skor kepraktisan isi dari respon mahasiswa dengan interval 3,5- $\leq 4,0$ termasuk dalam kategori sangat baik. Produk buku ilmiah populer Bungur (Lagerstroemia speciosa) ini memiliki kelebihan seperti aspek tampilan pada desain terdapat gambar asli dengan semenarik mungkin, aspek kelengkapan materi/isi erat kaitannya dengan lingkungan sekitar diharapkan mampu memunculkan keingintahuan untuk mempelajari, dan aspek bahasa yang sederhana dan mudah dipahami semua kalangan. Menurut Harlis, H., \& Budiarti, R. S. (2017) bahwa bahan ajar yang berkaitan dengan lingkungan sekitar mahasiswa dapat meningkatkan motivasi dan pemahaman mahasiswa karena bersentuhan langsung dan dapat terasimilasi dengan cepat dengan konsep sains yang telah dimiliki. Anggereini, E. (2017) juga menambahkan bahwa bahan ajar yang berkaitan langsung dengan lingkungan sekitar mahasiswa dapat meningkatkan rasa peduli mahasiswa terhadap lingkungan sekitar. Dengan demikian maka nilai-nilai perilaku pro environmental pada mahasiswa dapat mendukung upaya menjaga lingkungan hidup berkelanjutan (Sustainable Environment). 


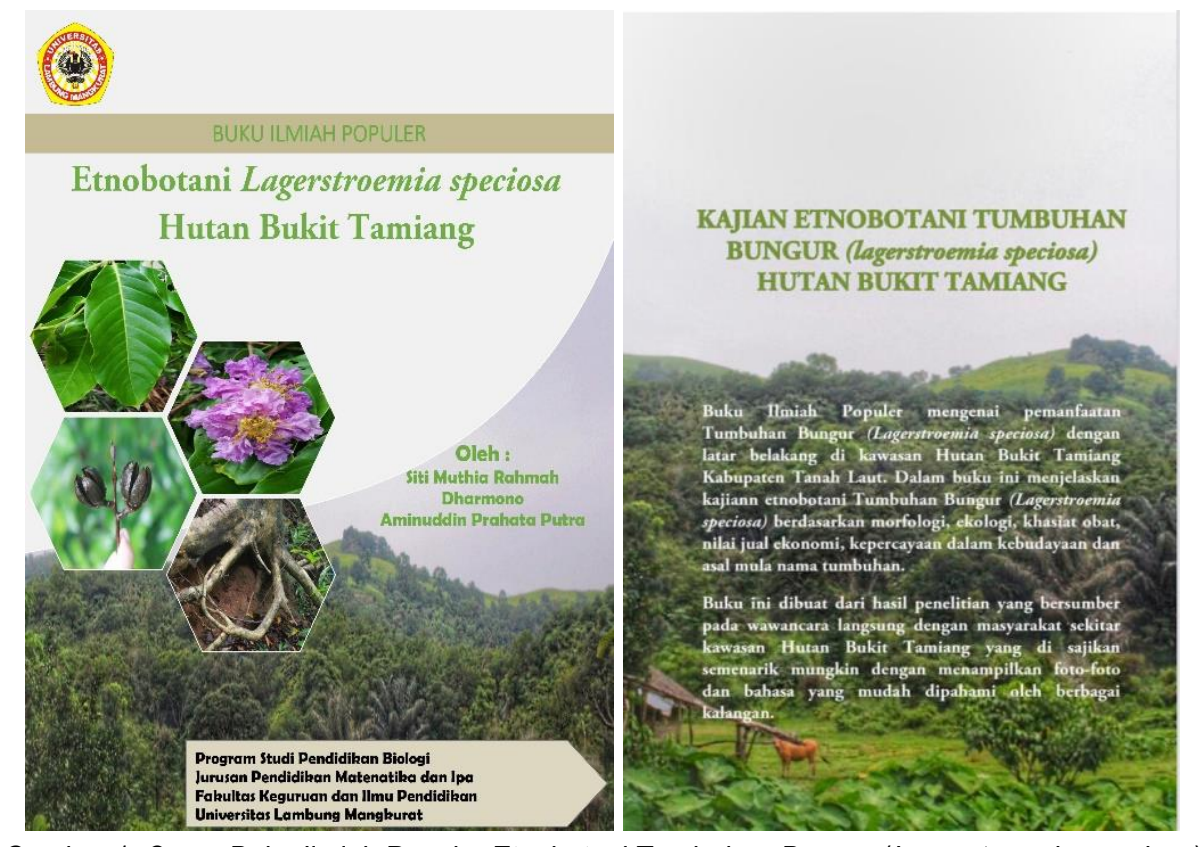

Gambar 1. Cover Buku Ilmiah Populer Etnobotani Tumbuhan Bungur (Lagerstroemia speciosa)

\section{KESIMPULAN}

Berdasarkan hasil penelitian pengembangan terhadap kajian etnobotani tumbuhan Bungur (Lagerstroemia speciosa) di kawasan Hutan Bukit Tamiang sebagai bahan ajar berbentuk buku ilmiah, dapat disimpulkan: (1) Kajian botani tumbuhan Bungur (Lagerstroemia speciosa). memiliki habitus pohon, arah tumbuh tegak lurus, percabangan simpodial, batang berwarna coklat yang berbentuk bulat. Akar tunggang bulat serabut, daun tunggal dengan tata letak berseling, bunga tunggal bentuk terompet, buah majemuk berbatas, tipe buah sejati tunggal kering warna hijau saat muda dan warna coklat saat tua. Kajian farmakologi digunakan untuk mengobati stroke, sakit gigi, bisul dan batuk. Kajian ekologi digunakan sebagai penghijauan hutan dan hiasan jalan. Kajian antropologi sebagai penanda musim hujan dan penjaga buah tumbuhan lain. Kajian ekonomi sebagai kayu bakar, pondok dan pagar ternak. Serta kajian linguistik dengan nama bungur. (2) Validitas buku ilmiah populer mendapatkan skor ratarata oleh 2 validator, yaitu 90,3\% dengan kriteria sangat valid. (3) Kepraktisan buku ilmiah populer yang dilakukan oleh 3 orang mahasiswa Pendidikan Biologi FKIP ULM yang telah lulus mata kuliah Etnobotani mendapatkan skor rata-rata 3,7 dengan kriteria sangat baik pada uji perorangan.

\section{UCAPAN TERIMA KASIH}

Penyelesaian penulisan jurnal ini tidak terlepas dari bantuan beberapa pihak oleh sebab itu penulis sangat berterimakasih kepada:

1. Orang tua penulis

2. Dosen pembimbing dari Magister Pendidikan Biologi ULM.

3. Staff administrasi Magister Pendidikan Biologi

4. Team peneliti

Tanpa bantuan pihak-pihat diatas penulis tidak akan bisa menyelesaikan penelitian dengan baik oleh sebab itu dengan segala hormat penulis ucapkan terima kasih. 


\section{DAFTAR PUSTAKA}

Aminuddin Prahatama Putra (2016). "The Use of Moral Dilemma Worksheet on the Issue of Forest Ecosystem through Science Learning at SMPN 6 Banjarmasin". Proceedings International Seminar (The 1st International Conference on Innovation and Commercialization of Forest Product (2016). 17-24.

Anggereini, E. (2017). Pengembangan E-Modul Pembelajaran Lingkungan Hidup Terintegrasi Nilai-Nilai Perilaku Pro Environmental dengan Aplikasi 3D Pageflip Profesional untuk Siswa SMA Sebagai Upaya Menjaga Lingkungan Hidup Berkelanjutan (Sustainable Environment). BIODIK, 3(2), 8191. https://doi.org/10.22437/bio.v3i2.5499

Arikunto, S. and Said, A. (1998). Pengembangan Program Muatan Lokal (PPML). Jakarta: Departemen Pendidikan dan Kebudayaan, Proyek Peningkatan Mutu Guru Kelas Setara D-II.

Bramasto, Y. (2015). TREES OF THE CITY Profil Tanaman Hutan untuk Perkotaan Wilayah Jawa Barat, Banten dan DKI Jakarta. Penerbit Balai Penelitian Teknologi Perbenihan Tanaman Hutan: Jakarta

Cronquist, A. (1981). An Integrated System of Classification of Flowering Plants. New York: Columbia University Press, 477.

Dalimartha, S. (2003). Atlas Tumbuhan Obat Indonesia Jilid II. Jakarta: Trubus Agriwidya

Dharmono. (2007). Kajian Etnobotani Tumbuhan Jalukap (Centella asiatica L.) di Suku Dayak Bukit Desa Haratai 1 Loksado. Jurnal Bioscientiae, 4(2) 71-78. https://doi.org/10.18860/jt.v0i0.2190.

Dwiyani R. (2013). Mengenal Tanaman Pelindung di Sekitar Kita. Denpasar: Udayana University Press:

Fitriansyah, M., Arifin, Y. D., \& Biyadmoko, D. (2018). Validitas Buku IImiah Populer Tentang Ecinodermata di Pulau Sembilan Kota Baru Untuk Siswa SMA di Kawasan Pesisir. Jurnal Bioedukatika. 6(1) 31-39.

Hakim., L. (2014). Etnobotani dan Manajemen Kebun-Pekarangan Rumah: Etnobotani dan Manajemen KebunPekarangan Rumah: Ketahanan Pangan, Kesehatan dan Agrowisata, 1-279.

Hardiansyah, Noorhidayati, \& Mahrudin. (2018). Keragaman Jenis Vegetasi Di Kawasan Rawa Tanpa Pohon Desa Bati-Bati Kabupaten Tanah Laut Sebagai Bahan Pengayaan Materi. Prosiding Seminar Nasional Lingkungan Lahan Basah, 3(1), 170-175.

Harlis, H., \& Budiarti, R. S. (2017). Pengembangan bahan ajar praktikum dan instrumen penilaian berbasis keterampilan proses sains pada mata kuliah mikologi program studi pendidikan biologi universitas jambi. BIODIK, 3(2), 102-112.

Hera, R., Khairil, and Hasanuddin. (2014). Pengembangan Handout Pembelajaran Embriologi Berbasis Kontekstual Pada Perkuliahan Perkembangan Hewan Untuk Meningkatkan Pemahaman Konsep Mahasiswa Di Universitas Muhammadiyah Banda Aceh. Jurnal EduBio Tropika, 2(2), 223-229.

Heyne K. (1987). Tumbuhan Berguna Indonesia. Jakarta: Koperasi Karyawan Departemen Kehutanan.

IUCN, (2014). Guidelines for Using the IUCN Red List Categories and Criteria. Version 11 Prepared by the Standards and Petitions Subcommittee.

Liu, F., Kim, J. K., Li, Y. and Chen, X. (2001). An Extract of Lagerstroemia speciosa L. Has Insulin-Like Glucose Uptake-Stimulatory and Adipocyte Differentiation-Inhibitory Activities in 3T3-L1 Cells1. Jurnal National Library of Medical. (2)3. 189-199.

Mahrudin, \& Dharmono. (2018). Pengembangan handout struktur populasi tumbuhan kawasan ekologi tumbuhan. Prosiding Seminar Nasional Lingkungan Lahan Basah, 3(2), 563-567. Retrieved from http://snllb.ulm.ac.id/prosiding/index.php/snllb-lit/article/view/122

Mardiah S, Aminuddin P. P., and Atiek, W. (2018). "The Practicality and Effectiveness of Lesson Plan Set on the Topic of Digestive System in Training the Critical Thinking Skills of Junior High School Students". European Journal of Education Studies. 4 (7): 21-32. http://snllb.ulm.ac.id/prosiding/index.php/snllblit/article/view/122.

Martin, G. J. (1998). Etnobotani : Sebuah Manual Pemeliharaan Manusia dan Tumbuhan. Edisi Bahasa Melayu Terjemahan Maryati Mohamed, Natural History Publications (Borneo) Malaysia: Sabah.

Suryadarma. (2008). Diktat Kuliah Etnobotani. Yogyakarta: Jurusan Pendidikan Biologi FMIPA Universitas Negeri Yogyakarta.

Suradji dan Mey S. (2017). Perbenihan Tanaman Hutan (Lagerstroemia speciosa) . jurnal informasi singkat benih no.105. BPTH Sumatera

Suryani, D., Nur, M., \& Wasis, W. (2017). Pengembangan Prototipe Perangkat Pembelajaran Fisika SMK Model Inkuiri Terbimbing Materi Cermin untuk 74 Melatihkan Keterampilan Berpikir Kritis. JPPS: Jurnal Penelitian Pendidikan Sains, 6(1), 1175-1183. 
Suzuki, Y., and Kakuda. (1999). Anti obesity activity of extracts from Lagerstroemia speciosa L. leaves on female kk- Ay mice. Journal of Nutrition. (4)5. 791-795.

Putri, A. I., Dharmono., \& Zaini. M. (2020). Validitas Buku IImiah Populer Keanekaragaman Spesies Famili Fabaceae Dalam Meningkatkan Keterampilan Proses Sains Mahasiswa. Jurnal Inovasi Pendidikan Sains. 2(11) 186-195.

Wibowo, A. M. (2012). Peningkatan Pemahaman Konsep Sains Di Madrasah Ibtidaiyah Melalui Perbaikan Bahan Ajar. Madrasah, (1992), 161-172. https://doi.org/10.18860/jt.v0i0.2190.

Yunizarrakha, E., Supramono, and Soendjoto, M. A. (2018) Pengembangan Bahan Ajar Tentang Jenis-jenis Reptil (Ordo Squamata dan Chelonia) Terhadap Kemampuan Berpikir Kritis. Tesis Magister Pendidikan, Universitas Lambung Mangkurat, Banjarmasin. 